\title{
Studi Fenomenologi Konsep Sehat Sakit Keluarga denga Demam Berdarah Dengue di Kota Padang
}

\author{
Jhunesti Pratiwi ${ }^{a}$ Fitra Yeni ${ }^{a}$, \\ ${ }^{a}$ Fakultas Keperawatan Unand
}

\begin{abstract}
Dengue fever is a disease caused by a virus that can cause dangerous because the patient died whitin a very short time, wich is transmitted by the mosquito Aedes Aegypty. Family experience who success treating patients with dengue fever in the shock phase is very important for the family to be a lesson. Purpose of this study is to explore, understand, and give meaning to the concept of a healthy experience in caring for family members who where suffering from dengue fever. This research is a qualitative descriptive with phenomenological approach with three informants in Padang city in 2013. The results of this study found that families who successfully treated patients with dengue fever until recover have good management practices and they follow the advice of medical personnel to prevent misconduct in taking care of patients. Families need to get an explanation from medical officers in order to take good and right action so the death rate from dengue fever can be avoided.
\end{abstract}

Key words : dengue fever, concept of a healthy, family experience

\begin{abstract}
Abstrak: Demam Berdarah Dengue (DBD) adalah penyakit yang disebabkan olehvirus yang berbahaya karena dapat menyebabkan penderita meninggal dalam waktu yang sangat pendek, yang ditularkan oleh nyamuk Aedes Aegepty. Pengalaman keluarga yang berhasil merawat penderita DBD pada fase syok sangat penting bagi keluarga lain untuk dijadikan pelajaran. Tujuan penelitian ini adalah untuk mengeksplorasi, memahami dan memberi makna dari pengalaman konsep sehat sakit keluarga dalam merawat anggota keluarga yang menderita DBD. Penelitian ini bersifat kualitatif dengan pendekatan fenomenologis deskriptif, dengan 3 orang informan di Kota Padang tahun 2013. Hasil penelitian ini didapatkan bahwa keluarga yang berhasil merawat penderita DBD sampai pulih melakukan perawatan yang baik dengan mengikuti saran dari petugas medis agar tidak terjadi kesalahan tindakan pada pasien. Keluarga pun perlu mendapat penjelasan dari petugas medis agar bisa mengambil tindakan yang baik dan benar agar angka kematian akibat DBD dapat dihindari.
\end{abstract}

Kata Kunci: DBD, konsep sehat sakit, pengalaman keluarga

Demam Berdarah Dengue (DBD) adalah penyakit virus yang sangat berbahaya karena dapat menyebabkan penderita meninggal dalam waktu yang sangat pendek (beberapa hari), yang ditularkan oleh nyamuk Aedes Aegepty, ditandai dengan deman tinggi dan manifestasi perdarahan (Irawan, 2008

Penyakit Demam Berdarah Dengue (DBD) ini dapat dikendalikan dan penderitanya tidak perlu mengalami keadaan yang parah. Penderita dapat diselamatkan dari kondisi yang fatal jika penderita segera diberi perawatan yang tepat. Namun, proses penyembuhan penyakit DBD akan lebih semakin cepat jika keluarga turut membantu perawatan penderita DBD. (Campbell, 2000).

Upaya yang dapat dilakukan keluarga dalam merawat anggota keluarga yang menderita DBD adalah mengenali gejala awal DBD. Memang, tidak mudah menentukan seseorang menderita DBD atau tidak. Hal ini dikarenakan, penyakit yang disebabkan oleh 
virus dengue ini sering menimbulkan gejala yang samar. (Kasdu, Meiliasari, Handoko., 2009).

\section{METODE}

Metode penelitian yang digunakan adalah metode kualitatif dengan pendekatan fenomenologis deskriptif (Polit \& Beeck, 2004).

Populasi pada penelitian kualitatif merupakan suatu fenomena atau situasi social yang akan diteliti (Speziale \& Carpenter, 2007). Populasi dalam penelitian adalah 3 orang. Jumlah informan yang direkomendasikan oleh Rieman (1986) dikutip dari Creswell (2002) yaitu 3-10 orang partisipan, bila informasi sudah tercapai, maka pengambilan data dihentikan. Pemilihan informan berdasarkan prinsip kesesuaian (approprieteness) dan kecukupan (adequacy). Teknik pengambilan informan dalam penelitian ini adalah teknik purposive sampling. Purposive sampling yaitu pemilihan sampel dengan pertimbangan tertentu, informan dipilih berdasarkan kriteria dan tujuan penelitian (Sugiyono, 2007). Sesuai kriteria yang telah ditentukan oleh peneliti, maka informan dalam penelitian ini berjumlah sebanyak 3 orang. Penelitian dilakukan di Kota Padang dan pengambilan data dimulai dari bulan Februari 2013 - Mei 2013.

Instrumen penelitian adalah pedoman wawancara, dan voicerecorder. Pengumpul data utama dalam penelitian ini adalah peneliti sendiri.

Metode yang digunakan dalam pengumpulan data adalah wawancara mendalam (indepth interview) dan observasi (Speziale \& Carpenter, 2007).

Secara umum, pengolahan dikenal sebagai istilah codingyang dibutuhkan untuk membuat pertanggungjawabkan data penelitian dan analisis. Pada coding kualitatif, penelitian mengembangkan kategori coding untuk menunjukan tema penting dalam data (Polit dkk, 2004).

Pada studi kualitatif, interprestasi dan analisis data terjadi secara stimultan. Peneliti telah mengkategorikannya, mengembangkan analisa tematik dan menyatukan tema. Usaha untuk menvalidasi analisa data dilakukan sebaik mungkin.

Menurut Giorgi (1985) dikutip dari Speziale \& Carpenter (2007) langkah-langkah analisis data adalah sebagai berikut : membuat verbatim informasi dari informan dalam bentuk narasi yang bersumber dari hasil wawancara dan catatan lapangan, membaca kembali secara keseluruhan deskripsi informasi dari informan untuk memperoleh perasaan yang sama seperti pengalaman informan, mengidentifikasi kata kunci melalui penyaringan pernyataan informan yang signifikan dengan fenomena yang diteliti, memformulasikan arti dari kata kunci dengan cara mengelompokan lagi kata kunci yang sejenis, mengorganisasikan arti arti yang teridentifikasi dalam beberapa kelompok tema. Setelah tema-tema terorganisir, peneliti menvalidasi kembali kelompok tema tersebut, mengintegrasikan semua hasil penelitian kedalam suatu narasi yang menarik dan mendalam sesuai topik penelitian.

\section{HASIL DAN PEMBAHASAN}

Dari jawaban ketiga informan tentang pengetahuan keluarga dalam pencegahan penyakit DBD dapat digambarkan bahwa setiap keluarga mempunyai pengetahuan yang cukup baik yaitu tahu bagaimana cara melakukan pencegahan penyakit demam berdarah ini. Seperti 3M, membersihkan lingkungan tempat tinggal serta menggunakan anti nyamuk dan lotion anti nyamuk. Informasi-informasi tentang pencegahan DBD ini diperolah informan dari iklan televisi dan poster-poster yang ada di puskesmas, serta penyuluhan-penyuluhan dari petugas 
kesehatan. Secara keselurahan kebersihan rumah informan bisa terjaga, tetapi ada satu informan yang kerapian rumahnya tidak terjaga. Cara pencegahan DBD yang dilakukan oleh ketiga informan adalah dengan cara melakukan 3M, dan menjaga kebersihan rumah, selain itu informan juga menggunakan anti nyamuk seperti obat nyamuk bakar dan lotion nyamuk. Akan tetapi, masih ada tempattempat yang berpotensi untuk menjadi tempat berkembangbiaknya nyamuk Aedes Aegepty, masih ada kain yang tergantung di kamar. Adapun keterbatasan informan dalam membersihkan rumah adalah karena informan seorang pegawai swasta.

Secara keselurahan informan mengetahui bahwa tanda dan gejala dari DBD adalah demam yang turun naik selama 3-7 hari, dengan gejala lainnya yaitu mual, muntah, pusing, sakit kepala, sakit di persendian, dan keluarnya bintik-bintik merah dipermukaan kulit. Informan juga menyatakan bahwa penyakit DBD ini disebabkan oleh nyamuk Aedes Aygepty.

Tanda dan gejala yang dialami setiap keluarga informan hampir sama. Yaitu dengan mengalami demam yang turun naik selama 3 hari. Setiap keluarga informan juga berkeringat pada saat panas, dan kaki tangan keluarga informan juga teraba dingin. Keluarga informan juga mengalami pusing dan sakit kepala. Salah satu informan mengeluarkan darah dari hidungnya.

Cara pengambilan keputusan yang dilakukan keluarga untuk melakukan perawatan dapat digambarkan bahwa ada informan yang memeriksakan keluarganya setelah mendapat informasi dari tetangga. Ada juga yang langsung membawa keluarganya ke rumah sakit setelah melihat tanda dan gejala yang ada pada keluarganya. Ada juga informan menolak untuk melakukan rawat inap dengan alasan masih bisa merawat di rumah. Akan tetapi setelah kondisi keluarga semakin memburuk, informan kembali membawa informan ke rumah sakit untuk menjalani rawat inap.

Setiap inforaman mendapatkan kepastian penyakit keluarga setelah hasil laboraturium keluar. Selain itu ada juga informan yang mendapat kepastian dari keterangan dari petugas medis. Informasi tentang penyakit yang diderita keluarganya didapat dari petugas medis. Peran dan tanggung jawab keluarga lainnya tetap berjalan seperti biasa, hanya saja mereka lebih mandiri. Sedangkan peran Ibu (Informan) dapat digantikan oleh anggota keluarga yang lainnya. Yang bertanggung jawab dalam perawatan klien di rumah sakit adalah ibu. Cara keluarga dalam menjalankan proses penyembuhan informan lebih memperhatikan kesehatan keluargany, seoerti memperhatikan makanan dan minuman yang dikonsumsi klien.

Penyakit Demam Berdarah Dengue (DBD) ini merupakan salah satu penyakit yang dapat menimbulkan kekhawatiran masyarakat karena perjalanan penyakitnya yang cepat dan dapat menyebabkan kematian dalam waktu yang singkat (Irawan, 2008). Sampai saat ini, penyakit Demam Berdarah Dengue (DBD) merupakan penyakit yang sering menimbulkan kejadian luar biasa (KLB) di Indonesia.

Sudah banyak cara yang dilaksanakan oleh masyarakat dalam upaya pencegahan demam berdarah dengue ini, beberapa di antaranya adalah gerakan $3 \mathrm{M}$, penyemprotan atau fogging, pelaksanaan gotong royong membersihkan lingkungan, dan pembagian abate. Namun sampai saat ini penyakit DBD belum dapat ditanggulangi secara tuntas, penderita-penderita DBD masih tetap ada mengisi ruang perawatan di rumah sakit, bahkan ada yang meninggal dunia karena keterlambatan pemberian pertolongan (Sumihar, 2007).

Penyakit DBD tidak akan dapat diberantas jika hanya mengandalkan peran dari petugas kesehatan. Keterlibatan 
masyarakat yang tinggi sangat membantu dalam pencegahan penyakit DBD. Namun, ternyata masyarakat masih memiliki pengetahuan dan cara yang berbeda-beda dalam upaya pencehagan penyakit Demam Berdarah Dengue (DBD).

Penyakit Demam Berdarah Dengue (DBD) ini dapat dikendalikan dan penderitanya tidak perlu mengalami keadaan yang parah. Penderita dapat diselamatkan dari kondisi yang fatal jika penderita segera diberi perawatan yang tepat. Pelayanan kesehatan merupakan salah satu cara yang tepat dalam menangani penderita DBD. Namun, proses penyembuhan penyakit DBD akan lebih semakin cepat jika keluarga turut membantu perawatan penderita DBD. Apalagi, pada tahap awal penderita DBD dapat dirawat di rumah. Dalam hal ini, keluarga berperan penting dalam semua bentuk promosi kesehatan dan penurunan resiko. Penjelasanpenjelasan dari petugas medis dapat mengurangi rasa khawatir yang dialami keluarga. Selain itu, keluarga juga harus memberikan informasi-informasi yang benar tentang keadaan pasien, agar diagnosis yang dilakukan oleh petugas medis tepat dan benar.Pada saat penderita memasuki fase kritis, hal terpenting yang dilakukan keluarga adalah melihat perkembangan yang dialami penderita. Pemantauan yang dilakukan keluarga akan membantu petugas medis karena pada fase kritis ini kemungkinan fatal dapat terjadi. Selain itu keluarga juga diharapkan selalu menanyakan tentang keluhan-keluhan atau kondisi yang dialami penderita kepada petugas medis agar pertolongan dapat diberikan kepada penderita. Misalnya, pemberian transfuse darah dan obatobatan tertentu.

Ketakutan keluarga dengan penyakit yang dialami penderita, membuat keluarga lebih protektif dalam menjaga kesehatan penderita. Ketiga informan juga membebaskan penderita untuk tidak menjalankan peran dan tanggung jawabnya.Situasi yang paling diharapkan pada tahap pemulihan ini adalah kondisi yang terus membaik dan penderita benar-benar pulih. Namun, keluarga tetap siap dengan kondisi lain, seperti nafsu makan penderita yang tidak kunjung meningkat. Selain itu, mungkin timbul kondisi seperti perut menjadi kembung dengan atau tanpa penurunan atau menghilangnya bising usus. Biasanya bising usus dikarenakan oleh sisa darah dari perdarahan saluran cerna. Keadaan ini akan menghilang setelah penderita buang air besar

\section{KESIMPULAN DAN SARAN}

Pengetahuan keluarga tentang cara pencegahan penyakit demam berdarah dengue ini cukup baik, seperti dengan cara $3 \mathrm{M}$, dan membersihkan lingkungan rumah dari tempat yang menjadi tempat berkembangnya nyamuk Aedes Aegepty. Secara umum, keluarga telah melakukan cara-cara untuk menghindari tempat berkembangnya nyamuk Aedes Aegypti dengan tepat, tetapi masih ada beberapa hal kecil yang ditinggalkan keluarga dalam hal pencegahan DBD, seperti mengantung pakaian, dan genangan air di halaman rumah mereka. Padahal hal kecil itu dapat menjadi tempat berkembangnya nyamuk Aedes Aegypti.

Pada dasarnya informan memiliki pengetahuan tentang penyakit DBD dengan cukup baik, dan tahu bahwa gigitan nyamuk yang menjadi sumber penularan penyakit ini. Informan juga mampu memberikan penilaian terhadap tanda dan gejala yang dialami oleh penderita. Jadi dapat disimpulkan pengalaman keluarga dalam merawat penderita DBD dapat memberikan pengetahuan kepada anggota keluarga yang lain dengan adanya penjelasnpenjelasan yang diterima dari petugas medis.

Pada tahap pencarian perawatan yang dilakukan oleh keluarga adalah mendengar saran dan melihat pengalaman dari tetangga. 
Keluarga juga langsung memutuskan dalam pemberian perawatan setelah menerima saran dari lingkungannya. Penyakit Demam Berdarah Dengue (DBD) ini dapat dikendalikan dan penderitanya tidak perlu mengalami keadaan yang parah. Penderita dapat diselamatkan dari kondisi yang fatal jika penderita segera diberi perawatan yang tepat. Pelayanan kesehatan merupakan salah satu cara yang tepat dalam menangani penderita DBD.

Selain dalam mencari kepastian tentang penyakit yang diderita penderita, keluarga juga akan mencari penjelasan tentang gejala yang ada, penyebab timbulnya gejala, proses penyakit, dan implikasi penyakit terhadap kondisi kesehatannya di masa yang akan datang. Hal ini dilakukan informan agar bisa memberikan tindakan yang tepat agar tidak terjadi kesalahan dalam memberikan perawatan kepada penderita.

Penjelasan-penjelasan dari petugas medis dapat mengurangi rasa khawatir yang dialami keluarga. Selain itu, keluarga juga harus memberikan informasi-informasi yang benar tentang keadaan pasien, agar diagnosis yang dilakukan oleh petugas medis tepat dan benar. Karena penderita DBD sering mendapat diagnosis yang kurang tepat karena gejalanya mirip dengan penyakit infeksi lainnya.

Setiap keluarga yang anggota keluarga menderita penyakit DBD akan berusaha menjalani peran dan tanggung jawab seperti biasa dan menggantikan peran yang dilakukan penderita.Sikap positif yang ditunjukan keluarga kepada penderita akan membantunya mengahadapi sakit dengan lebih sabar dan kuat. Memang, sangat manusiawi jika keluarga merasa khawatir. Namun, sebaiknya keluarga menyimpan kekhawatiran itu dan tidak menunjukannya kepada penderita. Jika perlu menumpahkan rasa khawatir itu, pilih orang yang memiliki wawasan yang memadai tentang penyakit DBD ini dan dapat menenangkan keluarga.
Situasi yang paling diharapkan pada tahap pemulihan adalah kondisi yang terus membaik dan penderita benar-benar pulih. Ketakutan keluarga dengan penyakit yang dialami penderita, membuat keluarga lebih protektif dalam menjaga kesehatan penderita. Keluarga memberi batasan untuk bermain kepada penderita dan lebih memperhatikan asupan nutrisi penderita. Dalam tahap pemulihan keluarga diharapkan mengikuti saran-saran dari petugas medis. Jika penyembuhan tidak dilakukan dengan tepat, maka perawatan jangka panjang mungkin perlu dilakukan sebelum klien mampu mencapai tingkat fungsi yang optimal.

SARAN

Keluarga diharapkan lebih memperhatikan hal-hal kecil yang menjadi penyebab penyakit Demam Berdarah Dengue (DBD). Keluarga juga diharapkan memberikan penanganan yang tepat seperti mengikuti saran-saran dari petugas medis agar tidak terjadi akibat yang fatal dan merugikan penderita.

Diharapkan kepada petugas kesehatan agar memberikan penjelasanpenjelasan mengenai kondisi maupun cara perawatan yang tepat bagi keluarga agar setiap keluarga yang menderita DBD bisa tenang dan tidak panik serta dapat memberikan tindakan yang sesuai untuk penderita

Kepada peneliti selanjutnya disarankan untuk mengadakan penelitian secara kuantitatif untuk mengetahui bagaimana pemahaman keluarga dalam melaksanakan tahapan-tahapan dari konsep sehat sakit keluarga dalam merawat anggota keluarga yang menderita DBD.

\section{DAFTAR PUSTAKA}

Alsa, A. (2004). Pendekatan kuantitaif dan kualitatif serta kombinasinya dalam 
penelitian psikologis. Yogyakarta: Pustaka Belajar.

Creswell, J.W. (2002). Research design; qualitative and quantitative approach. California: Sage Publication.

Dinas Kesehatan Indonesia. (2012). Profil kesehatan Indonesia 2012. Diakses pada tanggal 18 Februari 2013 darihttp://www.depkes.go.id/

Dinas Kesehatan Kota Padang. (2012). Profil kesehatan kota Padang tahun 2012. Diakses pada tanggal 18 Februari 2013 dari https://www.dinkes-padang.go.id/

Dinas Kesehatan Kota Padang. (2013). Laporan tahunan dinas kesehatan kota padang 2013.

Friedman, MM. (2004). Family nursing. $4^{\text {th }}$ Ed. Connecticut: Appleton and Lange.

Hadinegoro, Sri Rezeki \& Hindra Irawan. (2008). Demam berdarah dengue. Naskah lengkap pelatihan bagi pelatif dokter spesialis anak dan dokter spesialis penyakit dalam, dalam tatalaksana kasus DBD. Jakarta: Balai Penerbit FKUI

Hendro, D. (2011). Kamus ilmiah dengan EYD dan pembentukan istilah serta akronim bahasa Indonesia. Yogyakarta: Bintang Cemerlang.

Hidayah, A.N. (2009). Skripsi tingkat pengetahuan, sikap dan praktek keluarga tentang pencegahan demam berdarah dengue di $R W 09$ Kelurahan Kramatpela Kecamatan Kebayoran Baru Jakarta Selatan. Jakarta: Universitas Islam Negeri (UIN) Syarif Hidayatullah.

Kasdu, Dini; Meiliasari \& M. Nur Handoko. (2009). A-Z kesehatan anak. Jakarta: 3G Publisher.

Potter \& Perry. (2005). Fundamentals of nursing : concepts, process, and practice (edisi 4 volume 1). Jakarta: EGC.

Satari, L. (2009). Demam berdarah dengue. Jakarta: Puspa Swara. 